\title{
Evaluation of Patients with an Initial Diagnosis of Chorea: Sydenham Chorea and Differential Diagnoses
}

\section{Kore Ön Tanılı Hastaların Değerlendirilmesi: Sydenham Koresi ve Ayırıcı Tanılar}

\author{
Tugce Aksu Uzunhan ${ }^{1}$, Ahmet Irdem ${ }^{2} \odot$ \\ ${ }^{1}$ Department of Pediatric Neurology, Prof. Dr. Cemil Tascioglu City Hospital, istanbul, Turkey \\ ${ }^{2}$ Department of Pediatric Cardiology, Prof. Dr. Cemil Tascioglu City Hospital, Istanbul, Turkey
}

Received: 02.04.2020 / Accepted: 06.08.2020 / Published Online: 29.12.2020

Cite as: Aksu Uzunhan T, Irdem A. Evaluation of patients with an initial diagnosis of chorea: Sydenham chorea and differential diagnoses. Med J Bakirkoy 2020;16(4):355-62.

\begin{abstract}
Objective: Our aim is to evaluate patients being referred with an initial diagnosis of chorea according to their clinical, laboratory features and final diagnoses while emphasizing cardiological findings of patients with Sydenham chorea.

Method: Children aged 4-18 years who were referred to Okmeydanı Research and Training Hospital Pediatric Neurology department with an initial diagnosis of acute, subacute chorea between January 2017-January 2020 were retrospectively included. Chronic chorea and diseases associated with chronic chorea were excluded from the study. Data concerning clinical, laboratory features, cardiological findings, etiologies, treatments, recurrence rates and follow-ups of patients were recorded. Descriptive statistical analysis were performed using SPSS 21.0.

Results: Fifteen patients has been referred with the initial diagnosis of chorea. Mean age of the patients was 11.5 2.2 years. Ten (67\%) patients were females, 5 (33\%) patients were male. After admission, 8 (54\%) patients were diagnosed with Sydenham chorea, and 2 (13\%) patients with recurrent Sydenham chorea. During physical examination, $5(33 \%)$ patients did not have chorea, and 3 cases had tic disorder. Out of 8 patients with new diagnosis of Sydenham chorea, 3 (37.5\%) patients had subclinical carditis, and 5 (62.5\%) patients clinical carditis. Chorea had been treated with one of haloperidol/biperiden, valproic acid and prednisolon options. The treatment of 6 patients attending regular follow-up visits was stopped 2-6 months later. Chorea of two patients recurred during our follow-up, and one of our newly diagnosed Sydenham chorea patients had been recognized as antiphospholipid antibody syndrome after recurrence.

Conclusion: Sydenham chorea is the most common cause of acquired chorea in childhood. Most of the time it is self limiting. Differential
\end{abstract} diagnosis of chorea must be kept in mind especially when there is a recurrence.

Keywords: Antiphospholipid antibody syndrome, carditis, chorea, haloperidol, Sydenham chorea

öz

Amaç: Amacımız; kore ön tanısıyla yönlendirilen hastaların klinik ve laboratuvar özelliklerini, son tanılarını, Sydenham kore tanılı hastaların ise kardiyolojik bulgularını vurgulayarak değerlendirmektir.

Yöntem: Çalışmaya Okmeydanı Eğitim ve Araştırma Hastanesi Çocuk Nöroloji Polikliniği'ne Ocak 2017 - Ocak 2020 tarihleri arasında akut, subakut kore ön tanısı ile yönlendirilen 4-18 yaş arası hastalar retrospektif olarak dâhil edildi. Kronik kore ve kronik kore ile ilişkili hastalıklar çalışmadan dışlandı. Hastaların klinik ve laboratuvar özellikleri, kardiyolojik bulguları, etiyolojileri, tedavileri, rekürrens oranları ve izlemleri ile ilgili bilgiler kaydedildi. Tanımlayıcı istatistiksel analizler SPSS 21.0 kullanılarak yapıldı.

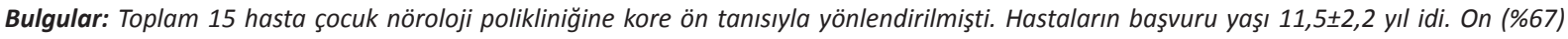
hasta kız, 5 (\%33) hasta erkek idi. Başvurudan sonra 8 (\%54) hastaya Sydenham koresi, 2 (\%13) hastaya rekürren Sydenham koresi tanıları kondu. Muayenede 5 (\%33) hastada kore saptanmadı, üç hasta tik bozukluğu olarak değerlendirildi. Yeni Sydenham koresi tanısı konulan 8 hastadan, $3(\% 37,5)$ hastada subklinik kardit, $5(\% 62,5)$ hastada klinik kardit vardı. Kore haloperidol/biperiden, valproik asit, prednizolon seçeneklerinden biri ile tedavi edildi. Düzenli takibe gelen 6 hastanın tedavisi 2-6 ay süre sonunda kesildi. İlemimizde rekürrens iki hastada oldu, ilk atak Sydenham koresi olan bir hasta rekürrens sonrası antifosfolipid antikor sendromu tanısı aldı.

Sonuç: Çocukluk çağında Sydenham koresi edinilmiş korenin en sık nedenidir. Genellikle kendi kendini sınırlar. Kore ayırıcı tanısı özellikle de rekürrens olduğunda akla getirilmelidir.

Anahtar kelimeler: Antifosfolipit antikor sendromu, haloperidol, kardit, kore, Sydenham kore 


\section{INTRODUCTION}

Chorea is a hyperkinetic movement disorder consisting of dance-like involuntary movements that travel from one part of the body to another (1). Traditionally, chorea has been classified as primary and secondary chorea. The term "primary" is used to refer to idiopathic or genetic chorea, while "secondary" indicates that the chorea is the result of an underlying disorder. Although there are other structural, autoimmune, metabolic, and drug/ toxin-induced etiologies of chorea, the most common type of childhood-onset chorea is Sydenham chorea, described in 1686 by Thomas Sydenham as a specific movement disorder. Although he wrote about his patient population in detail, he did not note its association with rheumatic fever (2). In 1810, Etienne Michel Bouteille recognized the association between Sydenham chorea and rheumatic fever in four of his patients ${ }^{(2)}$. The type of chorea known as Sydenham chorea is a major criteria for acute rheumatic fever (ARF) among all risk groups of patients according to the revised Jones criteria in $2015^{(3)}$. Carditis is the most common and feared manifestation of ARF as it results in permanent sequelae. In a study by Demirören et al., carditis diagnosed by echocardiography was accompanied by Sydenham chorea in $70.5 \%$ of 61 patients ${ }^{(4)}$.

Every hyperkinetic disorder, acute or subacute, is first presumed to be chorea by physicians so as to ensure a prompt diagnosis of ARF to prevent further damage to cardiac structures. However, it should be ascertained that the movement disorder is really chorea, followed by identification of the etiology. Although Sydenham chorea is the most common type of chorea, other etiologies are also possible. In the present study, we have evaluated symptoms, medical history, laboratory tests, cardiological findings, final diagnosis, treatment, and follow-up results in patients with an initial diagnosis of chorea.

\section{MATERIAL and METHOD}

Patients aged 4-18 years who were referred to the pediatric neurology department of Okmeydanı Research and Training Hospital with an initial diagnosis of chorea between January 2017 and January 2020 were retrospectively evaluated. Children with presumed acute and subacute chorea who were referred by a pediatrician or primary physician were included in the study. Patients with chronic chorea and diseases that lead to chronic chorea- like Huntington disease and choreoathetoid cerebral palsy were excluded from the disease. Chorea is a disorder characterized by continuous movements variable in speed, unpredictable in timing and direction, and flowing or jerky in appearance ${ }^{(5)}$. A detailed history was taken from all referred patients, who also underwent a physical examination in the pediatric neurology outpatient department to determine if they really had chorea.

Cardiac evaluation was performed by a pediatric cardiologist, and all patients underwent electrocardiography and echocardiography. A Hewlett-Packard Sonos 1000 system ultrasonic imager was used for echocardiographic assessments. Appropriate transducers of $2.5,3.5$, and $5 \mathrm{MHz}$ were used to define the cardiac structures. The echocardiographies were obtained with the patient in the standard precordial positions, and the diagnostic criteria of Gewitz et al. were used for the echocardiographic diagnosis of rheumatic disease ${ }^{(3)}$. The clinical diagnosis of carditis in an index attack of ARF is based on the presence of significant murmurs suggestive of mitral and/or aortic regurgitation or pericardial rub, or an unexplained cardiomegaly with congenital heart failure ${ }^{(6)}$. Subclinical carditis refers exclusively to the circumstance in which classic auscultatory findings of valvular dysfunction are either not present or not recognized by the diagnosing clinician, but echocardiography/Doppler studies reveal mitral or aortic valvulitis ${ }^{(3)}$. Carditis was treated with prednisolon when there was active inflammation with CRP and/or elevated sedimentation and moderate/severe valvular insufficiency and/or heart failure. Prednisolon treatment was ceased in 4-6 weeks. Arthritis was treated with ibuprofen sodium. Sodium and water restriction and enalapril and/or furosemid was used when there was evidence of volume load and heart failure (7). Secondary prophylaxis was performed every 21 days with intramuscular penicillin $\mathrm{G}$ benzathine $(1.2$ million units for patients weighing $27 \mathrm{~kg}$ or more and 600,000 units for those weighing less than $27 \mathrm{~kg}$ ) starting from the day of diagnosis in patients with ARF to eradicate group A carriage and to start the first dose of prophylaxis. 
Patient data including sex, age at presentation, duration of chorea until admission, duration of follow-up, complaints, bodily distribution, and severity of chorea, presence of tonsillitis within the last two months, final diagnosis, anti- streptolysin $\mathrm{O}$ titer, sedimentation rate, serum C-reactive protein levels, throat culture results, cardiological findings, treatment of patient, side effects of drugs, and recurrence rates were recorded from the medical files of patients. Chorea was classified according to localization (hemichorea, or movements affecting one side of the body; generalized movements affecting the whole body) and severity of the symptoms (mild, moderate, and severe). The severity of symptoms was determined by how much they interfered with dressing and other activities of daily living as well as school activities such as writing. Symptoms are described as mild when there are minimal movements; moderate chorea results in obvious inconvenience but does not interfere with self care; and severe chorea refers to movements that prevent the patient from performing daily activities meaning the patient requires assistance ${ }^{(8)}$. It is characterized by increased levels of antistreptolysin 0 titer $(>200 \mathrm{IU} / \mathrm{ml})$, eriyhrocyte sedimentation rate $(>30 \mathrm{~mm} / \mathrm{h})$, and C-reactive protein (CRP) $(>15 \mathrm{mg} / \mathrm{L}){ }^{(3)}$. Recurrence is described by Korn-Lubetzki et al. ${ }^{(9)}$ as the development of new signs lasting more than $24 \mathrm{~h}$ and separated by a minimum of two months from the previous attack ${ }^{(9)}$. At the time of recurrence, patients were assessed for rheumatic fever activity as well.

\section{Statistical analysis}

Statistical analyses were performed with SPSS software (version 21.0; SPSS Inc., Chicago, IL, USA). Descriptive statistical analysis (mean, standard deviation, median, frequency, percentage, minimum, maximum) were also performed.

\section{RESULTS}

Fifteen patients were referred to the pediatric neurology department with chorea as an initial diagnosis. The mean age of patients was $11.5 \pm 2.2$ years. Ten patients $(67 \%)$ were female and five $(38 \%)$ were male. Patients were followed up for a mean period of $5.47 \pm 5.75$ months; the minimum, maximum, and median follow-up periods were one month, 21 months, and three months, respectively. The symptoms of every patient are described in detail in Table 1. Symptom duration was 2-150 days with a median period of seven days. Antistreptolysin $\mathrm{O}$ titer results were available for 12 patients; one of them had normal levels, and the other 11 patients had levels ranging between 286, and $1500 \mathrm{IU} / \mathrm{ml}$ with a median of $550 \mathrm{lU} / \mathrm{ml}$. Erithrocyte sedimentation rate was available for 11 patients, which ranged between 4 , and $67 \mathrm{~mm} / \mathrm{h}$ with a median of $14 \mathrm{~mm} / \mathrm{h}$.C-reactive protein for 12 patients ranged between 0.22 , and 17 $\mathrm{mg} / \mathrm{L}$ with a median of $2.2 \mathrm{mg} / \mathrm{L}$. Out of seven patients for whom a throat culture was performed, in only one patient Group A $\beta$ hemolytic streptococcous was grown. Cranial MRI was performed in seven patients out of 15, all with normal results.Twelve patients had cardiological findings; the most common cardiological pathology was mitral valve insufficiency, and the second most common one was aortic insufficiency. Seven patients had two valve involvements at the same time. Three patients had normal echocardiographic findings, one of whom had been diagnosed with Sydenham chorea two months before admission to our instituition and was using carbamazepine. This patient had not any symptoms of chorea at the time of admission.

Final diagnoses, of the patients were Sydenham chorea in $8(54 \%)$, and recurrent Sydenham chorea in 2 $(13 \%)$ patients. Five (33\%) patients did not manifest symptoms of chorea during a physical examination. Two patients had a previous diagnosis of Sydenham chorea but were admitted with nonspecific symptoms not related to their previous diagnosis of Sydenham chorea. Three patients were diagnosed with tic disorder, the disease state of one of them had deteriorated after fluoxetin and metilphenidate use. All patients diagnosed with Sydenham chorea and recurrent Sydenham chorea and one patient with cardiac findings compatible with acute rheumatic fever without chorea were started on secondary prophylaxis. The patient who presented with severe hemichorea with a sedimentation rate of $67 \mathrm{~mm} / \mathrm{h}$ was found to have moderate mitral, and mild aortic insufficiency. This patient with clinical carditis, chorea, and laboratory signs showing ongoing inflammation, was started on prednisolon (1.6 mg/kg/day), and the chorea resolved after treatment with steroids as well. Another patient had been treated with oral prednisolon for four months before the presentation of chorea due to an 


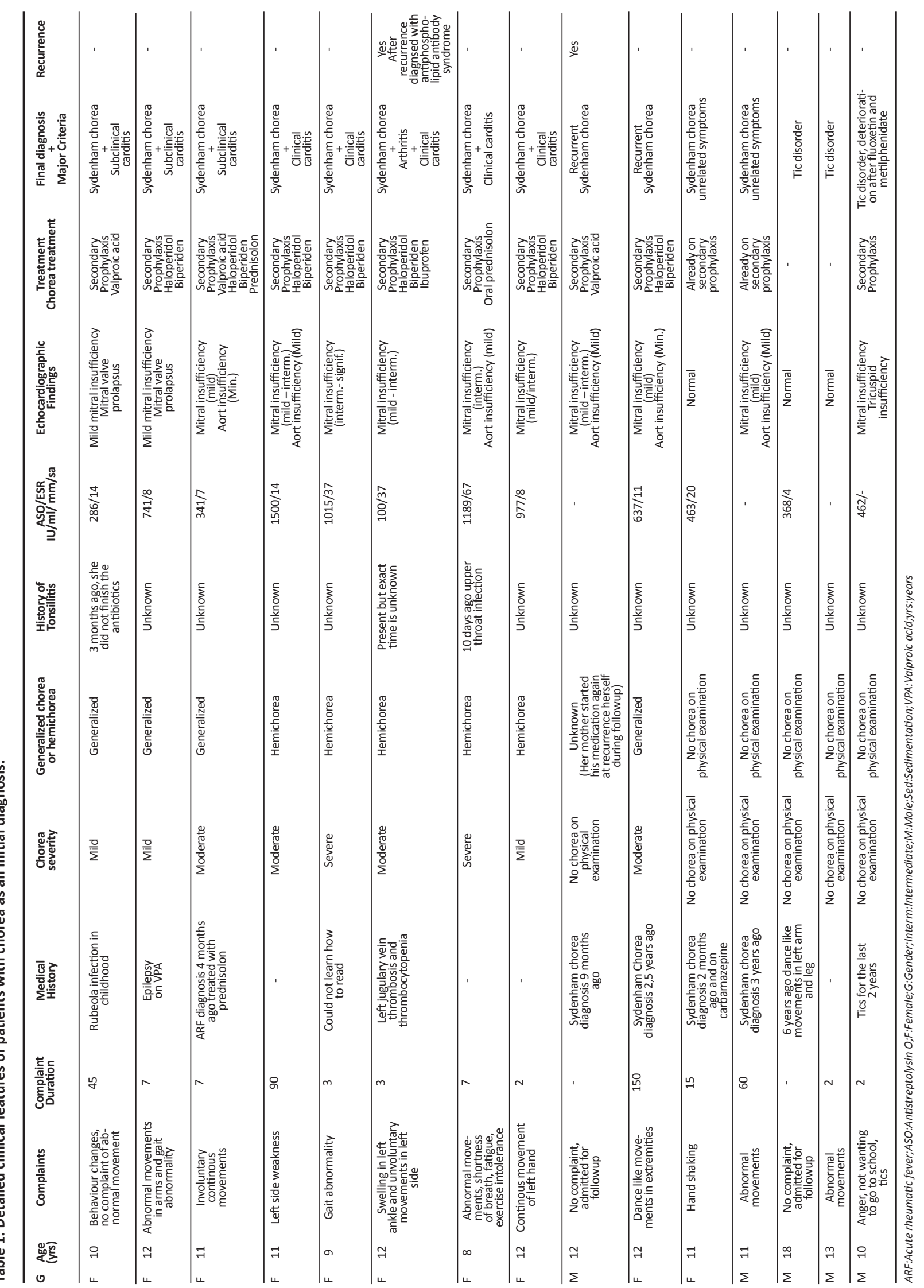


diagnosis of ARF with clinical carditis and active inflammatory laboratory signs at that time. These two patients were treated with enalapril/furosemide and enalapril consecutively. Of the eight patients with a new diagnosis of Sydenham chorea, three patients (37.5\%) had subclinical, and five patients (62.5\%) clinical carditis.

Six patients were started on haloperidol (doses ranging between $0.015-0.125 \mathrm{mg} / \mathrm{kg} / \mathrm{day}$ ), and all of them were treated with biperiden in addition to prevent dystonic reactions. For three patients, valproic acid was the first choice for chorea treatment; and these patients were treated with doses of 15, 20, and $22 \mathrm{mg} / \mathrm{kg} /$ day, respectively. One patient who had been diagnosed as ARF four months previously did not respond to valproic acid nor later to haloperidol/ biperiden. Therefore, she was started on oral prednisolon with a dose of $1 \mathrm{mg} / \mathrm{kg} /$ day, and her chorea diminished. Five patients responded completely to treatment, and five patients showed a partial improvement. Only one patient using haloperidol with a total dose of $5 \mathrm{mg}(0.125 \mathrm{mg} / \mathrm{kg} /$ day $)$ plus a total dose of $1 \mathrm{mg}$ of biperiden experienced tremors as a sign of parkinsonism as an adverse effect of haloperidol. When the patient stopped taking haloperidol, tremors of the patient disappeared. No other patient had any side effects with any other treatment. Six patients who were attending their pediatric neurology appointments regularly had their treatment stopped after 2-6 months without any symptomatology of chorea No patient had persistent chorea.

Recurrence occurred in two patients during our follow-up, although they stated that they did not delay secondary prophylaxis. One patient had a recurrence after he had been admitted without any symptoms for the purpose of follow-up after using valproic acid and had been been later followed up after ceasing treatment prescribed for his chorea. His mother started his medication again, and when he was admitted, he had no chorea. The other patient was diagnosed with Sydenham chorea at her first admission, which had recurred during her follow-up period. In her past medical history she had left jugular vein thrombosis and ongoing thrombocytopenia. When the etiology of her recurrence was investigated, her anticardiolipin Ig $\mathrm{G}$ and lupus anticoagulant levels were found to be increased. She was diagnosed with antiphospholipid antibody syndrome.Detailed clinical features of patients with presumed chorea are described in Table 1.

\section{DISCUSSION}

Chorea classically results from disturbances in the caudate nucleus or putamen. Occasionally, the pathology can involve thalamic/subthalamic region. Because of the vulnerability of the basal ganglia and its wide connections, the differential diagnostic spectrum of chorea is very large ${ }^{(10-12)}$. In the present study, ten patients out of 15 with an initial diagnosis of chorea had Sydenham chorea, and two of these were recurrences. In a Italian study evaluating hyperkinetic movement disorders in a pediatric emergency department, tics were the most common cause of admission (44.5\%) followed by tremors (21.1\%) and chorea (13.7\%) ${ }^{(13)}$; Sydenham chorea was the only form of chorea identified. As there is no specific biological marker in patients with Sydenham chorea, the diagnosis of Sydenham chorea is based on clinical evaluation and the exclusion of other causes of the chorea ${ }^{(14,15)}$. We diagnosed three patients with a tic disorder who had been initially thought to have chorea. Sydenham chorea must be differentiated from other hyperkinetic movement disorders like athetosis, ballism, chorea, dystonia, myoclonus, steropathy, tics, and tremor.

Sydenham chorea begins several weeks to months after a GAS infection. Although two major manifestations, or one major and two minor manifestations, with evidence of a preceding GAS infection are necessary for the diagnosis of ARF, chorea is an exception to this as chorea may be the only manifestation of ARF at the time of its presentation ${ }^{(3)}$. The onset of symptoms is usually insidious in the beginning with gradually progressive clumsiness and behaviour changes slowly increasing in frequency, and severity. Later, the choreic movements become more obvious and typically more generalized (16). Most commonly, changes include emotional lability and aggression, impulsivity, and obsessive- compulsive behaviour ${ }^{(16,17)}$. Behavioural changes may dominate the clinical picture more than a movement disorder;one of our patients had symptoms for almost 45 days without any complaint of involuntary movement. Hemichorea is also possible-almost 
half of our patients with chorea had hemichorea. Gurkas et al. reported hemichorea in $37.8 \%$ of their 90 patients, and Demirören et al. reported hemochorea in $20 \%$ of 65 patients ${ }^{(4,15)}$. Hemichorea can present with weakness; in one of our patients, this was the only complaint. Neuroimaging may be necessary when hemichorea is evident as structural basal ganglia etiologies like stroke, moyamoya disease, and vascular malformations can cause hemichorea ${ }^{(18,19)}$. Five of our chorea patients underwent cranial MRI with normal results.

Antiphospholipid antibody syndrome is one of the differential diagnoses of Sydenham chorea ${ }^{(18)}$. This chorea is most commonly unilateral, appears in a single episode, and regresses spontaneously or with medication ${ }^{(20)}$. The chorea associated with antiphosholipid antibodies has been reported to recur in $25-30 \%$ of patients ${ }^{(21)}$. Valvulopathies are also reported to be common in antiphospholipid antibody syndrome, with features making it surprisingly similar to Sydenham chorea ${ }^{(20,22)}$. After one of our patients had a recurrence compliant with secondary prophylaxis, she was tested positively for antiphospholipid antibody syndrome. She also had mild/intermediate mitral insufficiency. Although recurrences are possible without any delays in secondary prophylaxis, ${ }^{(23)}$ Gurkas et al. found that the risk factors for recurrence included the irregular use of antibiotic prophylaxis, failure to achieve remission within six months, and prolongation of symptoms for more than one year ${ }^{(15)}$.

The treatment of chorea falls into three categories: terminating exposure to the causative agent, symptomatic treatment, and treatment of the underlying etiology ${ }^{(18)}$. Although the pathophysiology of Sydenham chorea is still unclear, the crossreactivity of streptococcal antibodies with the basal ganglia and the brain cross-reactive epitopes of streptococcal M proteins are blamed in patients with Sydenham chorea ${ }^{(24,25)}$. As there is no permanent structural disability, the natural course of the disease is that it continues with a waxing and waning quality for 2-6 months until it finally resolves $(8,16,26)$. Therefore, most of the time, mild Sydenham chorea may not necessitate symptomatic treatment, however, we treated all our patients like some physicians, even mild ones ${ }^{(15,27)}$. If the chorea is moderate to severe, and gait is affected, treatment may be more warranted. We preferred haloperidol for most of our patients as it is a very effective treatment. Although haloperidol which is a typical antipsychotic, have side effects of dystonic reaction, somnolence, tardive dyskinesia, and parkinsonism; biperiden is used to correct these extrapyramidal side effects of haloperidol (28). As patients with Sydenham chorea are thought to be more vulnerable to the extrapyramidal side effects of typical antipsychotics than patients with other causes of chorea, ${ }^{(29)}$ a low dose of biperiden has been given simultaneously to patients with haloperidol in the present study. We had one patient with the side effect of parkinsonism without any dystonia who was taking haloperidol at a dose higher than our regular use. Other treatment options are valproic acid or carbamazepine ${ }^{(30)}$. Anti-inflammatory/immunomodulatory therapies (e.g., glucocorticoids, IVIG) are restricted to patients with severe chorea who have failed other modes of treatment ${ }^{(31)}$.

The widespread use of echocardiography has provided a way to diagnose carditis even in the absence of overt clinical findings, defined as subclinical carditis; the 2015 revision of the Jones criteria emphasizes the era of Doppler echocardiography ${ }^{(3)}$. Clinical carditis occurred in $37.5 \%$ of our patients with a new diagnosis of ARF who had Sydenham chorea as a major criteria; while the rest of our patients had subclinical carditis. In the literature subclinical carditis has been reported in 0\%-53\% patients with ARF ${ }^{322}$. With regard to patients specifically with Sydenham chorea, clinical and subclinical carditis has been reported in $31 \%$ and $50 \%$ of patients, respectively ${ }^{(33)}$. Anti-inflammatory treatment of carditis has been traditionally performed to prevent permanent sequelae; however, the 2003 Cochrane systematic review of clinical trials found that neither aspirin nor anti-inflammatory corticosteroid treatment improved cardiac outcomes at one year after diagnosis (34). In 2015, the same group reported that in clinical trials, little benefit was shown from the use of anti-inflammatory treatments for carditis ${ }^{(35)}$. In Turkey, ARF is the most common cause of valvular heart disease ${ }^{(36)}$. In the present study, we preferred to treat patients with carditis showing inflammation with corticosteroids as many physicians have done ${ }^{(37)}$ with the hope of preventing a major cause of morbidity and mortality in the young population. 
Although its retrospective nature, small number of patients, and short duration of follow-up were limitations of our study. Besides, we reported from a single center and from a relatively short duration of time with detailed patient features.

\section{Conclusion}

While investigating Sydenham chorea as the most common cause of pediatric chorea, we retrospectively evaluated patients with an initial diagnosis of chorea in the present study. Giving more importance to cardiac findings, laboratory test results were also analyzed. The differential diagnosis of chorea should be kept in mind in patients diagnosed with Sydenham chorea, especially when there is a recurrence. Hemichorea should not be missed, as weakness in one side may be present rather than a movement disorder. Haloperidol is still an important treatment option for Sydenham chorea, although it has significant side effects, particularly with high doses. Recognizing Sydenham chorea, a disease once thought to have disappeared in the modern world, is significant in the diagnosis of acute rheumatic fever. Conduction of further prospective studies examining its incidence, host factors, chorea-specific treatments, preventive strategies, and outcomes in children with Sydenham chorea is required.

Ethics Committee Approval: This study was approved by the ethical committee of Health Sciences University Okmeydanı Research and Training (31.03.2020 / 112).

Conflict of interests: No conflict of interest has been declared by the authors.

Funding: Any financial support was not received by the authors for the study.

Informed Consent: Legal guardians of all patients gave their written informed consent.

\section{REFERENCES}

1. Feinstein $E$, Walker R. An update on the treatment of chorea. Curr Treat Options Neurol. 2018;20(10):44. https://doi.org/10.1007/s11940-018-0529-y

2. Jummani RR, Okun MS. Sydenham chorea. Arch Neurol. 2001;58(2):311-3.

https://doi.org/10.1001/archneur.58.2.311

3. Gewitz MH, Baltimore RS, Tani LY, Sable CA, Shulman ST, Carapetis J, et al. Revision of the Jones Criteria for the diagnosis of acute rheumatic fever in the era of Doppler echocardiography: a scientific statement from the American Heart Association. Circulation.
2015;131(20):1806-18 https://doi.org/10.1161/CIR.0000000000000205

4. Demiroren K, Yavuz H, Cam L, Oran B, Karaaslan S, Demiroren S. Sydenham 's Chorea : A Clinical FollowUp. J Child Neurol. 2007;22(5):550-4. https://doi.org/10.1177/0883073807302614

5. Fahn S, Jankovic J. Chorea, Ballism, Athethosis: Phenomenology and Etiology. In: Principles and Practice of Movement Disorders. Philadelphia, PA: Churchill Livingstone/Elsevier; 2007. p. 393-407. https://doi.org/10.1016/B978-0-443-07941-2.50019-X

6. Goyal P, Vijayvergiya R. Rheumatic Fever and rheumatic heart disease. Int Encycl Public Heal. 2016;357-62. https://doi.org/10.1016/B978-0-12-803678-5.00385-4

7. Webb RH, Grant C, Harnden A. Acute rheumatic fever. BMJ. 2015;351:h3443. https://doi.org/10.1136/bmj.h3443

8. Aron AM, Freeman JM, Carter S. The natural history of Sydenham's chorea. Review of the literature and longterm evaluation with emphasis on cardiac sequelae. Am J Med. 1965;38:83-95. https://doi.org/10.1016/0002-9343(65)90162-2

9. Korn-Lubetzki I, Brand A, Steiner I. Recurrence of Sydenham chorea: implications for pathogenesis. Arch Neurol. 2004;61(8):1261-4. https://doi.org/10.1001/archneur.61.8.1261

10. Cardoso F, Seppi K, Mair KJ, Wenning GK, Poewe W. Seminar on choreas. Lancet Neurol. 2006;5(7):589602. https://doi.org/10.1016/S1474-4422(06)70494-X

11. Lee MS, Marsden CD. Movement disorders following lesions of the thalamus or subthalamic region. Mov Disord. 1994;9(5):493-507. https://doi.org/10.1002/mds.870090502

12. Gilbert DL. Acute and chronic chorea in childhood. Semin Pediatr Neurol. 2009;16(2):71-6. https://doi.org/10.1016/j.spen.2009.03.009

13. Raucci U, Parisi P, Vanacore N, Garone G, Bondone C, Palmieri $A$, et al. Acute hyperkinetic movement disorders in Italian paediatric emergency departments. Arch Dis Child. 2018;103(8):790-4. https://doi.org/10.1136/archdischild-2017-314464

14. Cardoso F. Sydenham's chorea. In: Handbook of Clinical Neurology. Vol. 100. Elsevier; 2011. p. 221-9. https://doi.org/10.1016/B978-0-444-52014-2.00014-8

15. Gurkas E, Karalok ZS, Taskin BD, Aydogmus U, Guven A, Degerliyurt $A$, et al. Predictors of recurrence in Sydenham's chorea: Clinical observation from a single center. Brain Dev. 2016;38(9):827-34. https://doi.org/10.1016/j.braindev.2016.04.010

16. Mink JW, Zinner SH. Movement disorders II: Chorea, dystonia, myoclonus, and tremor. Pediatr Rev. 2010;31(7):287-94; quiz 295. https://doi.org/10.1542/pir.31-7-287

17. Lubberdink AL, Sharif S, Pardhan K. You can dance if you want to: A case of Sydenham's chorea. Am J Emerg Med. 2019;37(11):2118.e5-2118.e7. https://doi.org/10.1016/j.ajem.2019.158414

18. Yilmaz S, Mink JW. Treatment of chorea in childhood. Pediatr Neurol. 2020;102:10-9. https://doi.org/10.1016/j.pediatrneurol.2019.08.013

19. Zomorrodi A, Wald ER. Sydenham's chorea in Western Pennsylvania. Pediatrics. 2006;117(4):e675-9. https://doi.org/10.1542/peds.2005-1573 
20. Peluso S, Antenora A, De Rosa A, Roca A, Maddaluno G, Morra VB, et al. Antiphospholipid-related chorea. Front Neurol. 2012;3:150. https://doi.org/10.3389/fneur.2012.00150

21. Cervera R, Piette JC, Font J, Khamashta MA, Shoenfeld Y, Camps MT, et al. Antiphospholipid syndrome: Clinical and immunologic manifestations and patterns of disease expression in a cohort of 1,000 patients. Arthritis Rheum. 2002;46(4):1019-27. https://doi.org/10.1002/art.10187

22. Reiner P, Piette J-C, Leroux G, Vidailhet M, CostedoatChalumeau N. Chorea, lupus and antiphospholipid antibodies. Rev Med Interne. 2012;33(4):206-8. https://doi.org/10.1016/j.revmed.2012.01.006

23. Berrios X, Quesney F, Morales A, Blazquez J, Bisno AL. Are all recurrences of "pure" Sydenham chorea true recurrences of acute rheumatic fever? J Pediatr. 1985;107(6):867-72. https://doi.org/10.1016/S0022-3476(85)80177-3

24. Bronze MS, Dale JB. Epitopes of streptococcal M proteins that evoke antibodies that cross-react with human brain. J Immunol. 1993;151:2820-8. PMID: 7689617.

25. Kiessling LS, Marcotte AC, Culpepper L. Antineuronal antibodies in movement disorders. Pediatrics. 1993;92:39-43. PMID: 8516083.

26. Van der Merwe PL, Kalis NN. Sydenham's chorea-analysis of 27 patients and a review of the literature. S Afr Med J. 1997;87 Suppl 3:C157-60. PMID: 9254767.

27. Crealey M, Allen NM, Webb D, Bouldin A, Sweeney NM, Peake D, et al. Sydenham's chorea: Not gone but perhaps forgotten. Arch Dis Child. 2015;100(12):11602. https://doi.org/10.1136/archdischild-2015-308693

28. Meszaros K, Lenzinger E, Hornik K, Schönbeck G, Hatzinger R, Langer $G$, et al. Biperiden and haloperidol plasma levels and extrapyramidal side effects in schizophrenic patients. Neuropsychobiology. 1997;3 6(2):69-72

https://doi.org/10.1159/000119365
29. Dean SL, Singer HS. Treatment of sydenham's chorea: A review of the current evidence. Tremor Other Hyperkinet Mov (N Y). 2017; 7:456. https://doi.org/10.5334/tohm.376

30. Oosterveer DM, Overweg-Plandsoen WCT, Roos RAC. Sydenham's chorea: a practical overview of the current literature. Pediatr Neurol. 2010;43(1):1-6. https://doi.org/10.1016/j.pediatrneurol.2009.11.015

31. Walker KG, Wilmshurst JM. An update on the treatment of Sydenham's chorea: the evidence for established and evolving interventions. Ther Adv Neurol Disord. 2010;3(5):301-9. https://doi.org/10.1177/1756285610382063

32. Tubridy-Clark M, Carapetis JR. Subclinical carditis in rheumatic fever: A systematic review. Int J Cardiol. 2007;119(1):54-8. https://doi.org/10.1016/j.ijcard.2006.07.046

33. Ozdemir O, Işık S, Abacı A, Hızlı S, Akelma AZ, Kışlal FM, et al. Silent enemy in acute rheumatic fever: subclinical carditis. Turk Kardiyol Dern Ars. 2011;39:41-6. Available from: https://www.journalagent.com/tkd/pdfs/ TKDA_39_1_41_46.pdf

34. Cilliers A, Manyemba J, Saloojee H. Anti-inflammatory treatment for carditis in acute rheumatic fever. ochrane Database Syst Rev. 2003;(2):CD003176. https://doi.org/10.1002/14651858.CD003176

35. Cilliers A, Adler AJ, Saloojee H. Anti-inflammatory treatment for carditis in acute rheumatic fever. Cochrane Database Syst Rev. 2015;(5):CD003176. https://doi.org/10.1002/14651858.CD003176.pub3

36. Demirbağ R, Sade LE, Aydın M, Bozkurt A, Acartürk E. The Turkish registry of heart valve disease. Turk Kardiyol Dern Ars. 2013;41(1):1-10. https://doi.org/10.5543/tkda.2013.71430

37. Köksal AO, Gültekin Soylu A, Özdemir O. Acute rheumatic fever. Turkish J Pediatr Dis. 2016;4:283-96. Available from: https://dergipark.org.tr/en/download/ article-file/684648 https://doi.org/10.12956/tjpd.2015.182 